\title{
Correction to: Airflow Considerations and the Effect of Webster's Triangle in Reduction Rhinoplasty
}

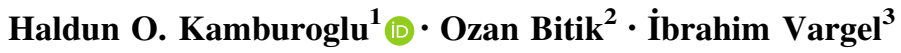

Published online: 23 March 2021

(C) Springer Science+Business Media, LLC, part of Springer Nature and International Society of Aesthetic Plastic Surgery 2021

\section{Correction to: Aesth Plast Surg}

https://doi.org/10.1007/s00266-021-02168-9

This article was updated to correct the level of evidence to 2.

Publisher's Note Springer Nature remains neutral with regard to jurisdictional claims in published maps and institutional affiliations.

The original article can be found online at https://doi.org/10.1007/ s00266-021-02168-9.

Haldun O. Kamburoglu

halonka@yahoo.com

1 Private Practice, Koc Ikiz Kuleleri A Blok No 57 Sogutozu, Cankaya, 06520 Ankara, Turkey

2 Private Practice, Ankara, Turkey

3 Department of Plastic, Reconstructive and Aesthetic Surgery, Hacettepe University Faculty of Medicine, Ankara, Turkey 